\title{
WALT WHITMAN "LIVE": PERFORMING THE PUBLIC SPHERE
}

\author{
Tyler HofFman
}

Others take finish, but the Republic is ever constructive and ever keeps vista.

-Whitman, from "By Blue Ontario's Shore"1

[T] he want for something finished, completed, and technically beautiful will certainly not be supplied by this writer, as it is by existing esthetic works.

-Whitman in conversation with Traubel ${ }^{2}$

WHITMAN IS NOT WELL KNOWN for having recited his poetry out loud to others and is on record as saying that he was "nothing of a reader," that, in fact, he preferred not to read his own work and couldn't recite it in any event, since he didn't have it memorized ( $W W W C, 3: 375)$. Despite such claims, he did perform on numerous occasions, both in private and in public, and attached great significance to those exercises. From his memoranda we know that he was in the habit of reading poetry aloud to himself from his youth, riding omnibuses up and down Broadway "declaiming some stormy passage from Julius Cæsar or Richard, (you could roar as loudly as you chose in that heavy, dense, uninterrupted street-bass.)." ${ }^{3}$ To his friend Horace Traubel in 1889 he recalled, "I did my best reading when I was alone that way-off in the woods or on the shore. Long ago, when I was a young man, Coney Island was a favorite spot. At that time Coney Island had not the reputation it has now-it was then a desert island-nobody went there. Oh yes! When I read, it was in solitude, never in frequented places, except perhaps, Broadway, on the stage-coaches, where a little noise more or less made no difference." Earlier that year, again to Traubel, he recounted of his lyric "A Voice Out of the Sea," "I always enjoyed saying it-saying it to the winds, the waters, the noisy streets - on stagecoaches. And one has love for the sound of his own voice-somehow it's always magnetic" ( $W W W C, 5: 321,463)$.

In discussion with Traubel about the practice of reading aloud, Whitman cites Ernest Legouvés The Art of Reading (translated into English in 1879), a copy of which he owned, explaining that in one of the chapters an actress named Rachel is described as being "aroused when going to her room and reading aloud her plays, whatnot," in part 
under the spell of her own voice; he concludes that "there are some who contend that no one can get a full or adequate idea of a poem till it is heard rendered aloud - the human voice to give it its free scope, ring!" and adds, "I don't know but there's a vast deal to be said to that effect" ( $W W W C, 5: 321$ ). Although Whitman does not say so, in this remark he picks up another thread in Legouvé's book, from the chapter "How Reading Reveals," where that author contends that "even reading aloud is not without its disillusions. If it discovers beauties, it detects faults as well. . . . How many writers and writings that I used to admire passionately, that possibly you admire passionately now, I have found totally unable to stand this terrible test!"4 Whitman tells Traubel that he always had tried his own poems-in-progress out by reading them aloud to himself "in a palpable voice" and by doing so was able "to get a new angle on them - see things I could not see in any other way" ( $W W W C$, $3: 375)$. In another conversation with his friend he notes that "the great French writer Legouvé says this is the final, the supreme, test, after all else is tried-how will a poem read, recite, deliver: with what effect? How will it hold its own when repeated? That is the court in which it must justify itself." While he says he would not give such a theory his "radical endorsement," Whitman regards it as one "not to be rejected scornfully" (WWWC, 4:116).

In his early years, Whitman shaped by hand his texts for ultimate portability, creating reading copies that he could take with him on site to declaim. On the cover of a reading copy of Shakespeare's Richard the Second that he made by tearing the leaves of the play out of a complete volume and binding them in wrapping paper, he wrote: "Had it put this shape to take in my pocket to Coney Island on my seashore jaunts-read it \& 'spouted' it there." ${ }^{5}$ Whitman also bundled together late in life a set of poems that he deemed "favorite" pieces for "spouting," and, pointing to the package of poems sitting on a chair, told Traubel, "I was a great spouter in my early days - even later on - had my favorite pieces - these among them" ( $W W W C, 5: 463$ ). He imagined the same fate for Leaves of Grass, saying on August 21, 1888, "I have long teased my brain with visions of a handsome little book at last . . . for the pocket. That would tend to induce people to take me along with them and read me in the open air: I am nearly always successful with the reader in the open air" ( $W W W C, 2: 175)$. This imagined pocket edition anticipates Gems from Walt Whitman (1889), in whose compilation Whitman assisted, Haldeman-Julius's Little Blue Books, and the beat poet Lawrence Ferlinghetti's populist City Lights "Pocket Books" series-a series that includes Allen Ginsberg's Howl. ${ }^{6}$

In a review of the 1855 edition of Leaves that he penned himself, Whitman, speaking of himself in the third person, explains the impor- 
tance of the spoken word to his art, stating that "in the scheme this man has built for himself the writing of poems is but a proportionate part of the whole. It is plain that public and private performance . . . have their equal call upon him and receive equal attention." Clearly, Whitman was not content to appear merely as a writer, wanting in addition to make an impression upon us as an oral performer, to simulate a live vocal presence. As he felt, the printed voice does not measure up to the "launch'd" voice and is, in the end, a sign of the artist's failure to prove his publicity, his complexion literally "pallid" from the lack of sunlight that comes of too much privacy: "Poets here [in America], literats here, are to rest on organic different bases from other countries; not a class set apart, circling only in the circle of themselves, modest and pretty, desperately scratching for rhymes, pallid with white paper, shut off, aware of the old pictures and traditions of the race, but unaware of the actual race around them-not breeding in and among each other till they all have the scrofula. Lands of ensemble, bards of ensemble!" $(P P, 1357)$. Indeed, the affective force of Whitman's verse, his desire to reach people directly, led him so far as to assert the importance of understanding his poetry as essentially not "literary," by which he means not figuratively dense but also not static and self-contained: "No one will get at my verses who insists upon viewing them as a literary performance . . . or as aiming mainly toward art or æstheticism” $(P P, 671)$. Whitman tied his rejection of the "literary" to oral performance more conspicuously in 1888, at the same time disavowing the title of "poet" as he makes his goal plain: "If they call me no poet then no-poet it may be. I don't care what they call me-by one name or another name-it is all one-so that I produce the result - so that I get my word spoken and heard-maybe move men and women" (WWWC, 2:150).

In light of his sense of the transformative power of utterance, Whitman is not always sanguine about the communicative capacity of the printed page, despairing at times, as he does in "The Unexpress'd," that "in poesy's voice or print- - [there is] something lacking" (PP, 653). Often ironically he would distance himself from the material conditions of print in his poems, referring to them as obstacles to be surmounted, obstacles that stand in the way of his ability to communicate with "power and pathos" ( $W W W C, 6: 365)$. The 1855 version of the poem eventually titled "A Song for Occupations" announces his distaste of the printed word, even as he must succumb to it: "I was chilled with the cold types and cylinder and wet paper between us. / I pass so poorly with paper and types ... . I must pass with the contact of bodies and souls" (LGVar., 1:84n). In "Now Precedent Songs, Farewell" he finds that some of the best of himself is left unremarked on the printed page: "From fibre heart of mine-from throat and tongue-(My life's 
hot pulsing blood, / The personal urge and form for me-not merely paper, automatic type and ink,) / Each song of mine-each utterance in the past-having its long, long history" (LGVar., 3:728). In "Song of the Open Road" he concedes that much simply is "untransmissible by print" and confesses in a hushed tone that "(I and mine do not convince by arguments, similes, rhymes, / We convince by our presence.)" (PP, 303) Indeed, Whitman favors terms such as "song," "chant," and "utterance" throughout his writings when describing his poetry.

Whitman's ambivalence was keen: he knows that he has little choice but to rely on the page to express his message to America, despite the reticence of the page, and so adopts strategies to breach the divide between script and speech. What we have in the case of Leaves is a text that promotes the fiction of its own liveness at every turn: we encounter as readers the presence of a physical speaker where we would expect absence. For Whitman, there was to be no difference between the book of poems and his own body and its voice: "Camerado, this is no book, / Who touches this touches a man" (PP, 611); "Indeed this is no book, but more a man, within whose breast the common heart is throbbing so much. These are no printed leaves, human lips $\mathrm{O}$ friend for your sake freely speaking" (NUPM, 4:1467). At the same time, no matter how often or how closely we read the poem on the page, Whitman insists, there are always other possible performances of it, with no two performances identical. ${ }^{8}$

As I argue, Whitman is the first American poet in a condition of "secondary orality" to prize liveness and to theorize and authorize a public poetry based on the phenomenology of liveness. ${ }^{9}$ Coming of age with the phonograph and other sound recording technologies, Whitman wanted his poems to be "felt, like the magnetism of a presence," but he sometimes worried about the vulnerability of the printed word to inauthenticity and manipulation in a mass-mediated society. ${ }^{10}$ In his performances on the page, through successive editions of Leaves, he foregrounds the communicative media of writing and voice, aligning and realigning his Americanism in provocative ways as he goes. I aim to show that Whitman's poetic texts - texts that exist in a state of changeintend to establish the poet's publicness through the performance of gender, political authority, and social relations for a nation in crisis.

\section{Power and Pathos: Audibilizing Masculine Sentiment}

Whitman's desire to declaim in public was not unique; it was informed by a culture caught up in the enthusiasms of the spoken word. Whitman's contemporary, Mark Twain, wrote from Philadelphia that he had taken part in "what is called a free-and-easy," an event that occurs 
"at the saloons on Saturday night, at which a chairman is appointed, who calls on any of the assembled company for a song or recitation, and as there are plenty of singers and spouters, one may laugh himself to fits at very small expense." 11 The saloon was established by midcentury as the social center for workers and the single men of boardinghouses, and the entertainment that it offered enacted the camaraderie that built group identity. The "free-and-easy" exemplifies the performative culture in which Whitman partook. While there is no evidence that Whitman performed at a "free-and-easy," Justin Kaplan reports that at "Pfaff's [a beer cellar on Broadway] during the first September of the war Walt read aloud from the manuscript of a new poem ["Beat! Beat! Drums!"] that was about to be published, almost simultaneously, in the Boston Evening Transcript, the New York Leader, and Harper's Weekly." 12 After the war, Whitman remembered fondly the close association he had had with the young men at Pfaff's, remarking that "we all loved each other more than we supposed"; although in retrospect he claimed that "my own great pleasure at Pfaff's was to look on-to see, talk little, absorb" - his performance as both auditor and orator there predicts his desire to construct and participate in a larger fraternal public sphere on the Pfaff's model (WWWC, 1:417)..$^{13}$

During the Civil War, Whitman performed in the intimacy of hospital wards, making a record of his recitals in his diary: "October 1st, 1863. Among other things in my visits to hospitals, I commence reading pieces" (NUPM, 2:537). Ten days later he wrote to Abby Price: "Then I read to the boys - the whole ward that can walk gathers round me \& listens." ${ }^{14}$ In Specimen Days he recalls that "in camp and everywhere, I was in the habit of reading or giving recitations to the men. They were very fond of it, and liked declamatory poetical pieces. We would gather in a large group by ourselves, after supper, and spend the time in such readings" (PP, 767). In this setting, he found another way to connect with men on sympathetic terms. For the first time in the 1871 version of "As I Sat Alone by Blue Ontario's Shore" Whitman tells of his ministrations in the camps and what he calls in Specimen Days the power of "personal presence," or "magnetism": "(Upon this breast has many a dying soldier lean'd to breathe his last, / This arm, this hand, this voice, have nourish'd, rais'd, restored, / To life recalling many a prostrate form;)" (PP, 751; LGVar., 1:205). In these lines we not only hear, but hear of, the salvific "voice," an appendage every bit as tangible as arm or hand, with the ability to resurrect dead soldiers.

Whitman kept up this practice of reading to small groups, though in a far different context, once the war was over. Herbert Gilchrist documented Whitman's visits to Gilchrist's mother's house in Philadelphia in 1876-1877, on one occasion noting that "in the evening Sunday 
he recited Tennyson's Ulysses grandly, and at my request the Mystic Trumpeter [one of Whitman's poems]. He said it exercised his lungs, the animal part - but that he did mostly this, and seldom entered into the spiritual part" ( $W W W, 31)$. Whitman's friend, Richard Maurice Bucke, reported that he had heard Whitman read "Mystic Trumpeter" "in a manner which singularly combined strong emphasis with the very realization of self-composure, simplicity and ease," further noting that "his voice is firm, magnetic, and with a certain peculiar quality we heard an admiring auditor call unaffectedness." 15 The poetics of naturalness that Bucke posits here-one that is without affectation but powerfully affective-is a sign of the times, as Whitman proposes to bring oratory in line with intimate conversation, to insist on the centrality of passionate speech as embodied in delivery to the project of persuasion and the communication of moral truths. ${ }^{16}$

As Whitman's fame grew, he was invited to perform his poetry at official celebrations and commemorations. He "spouted" his poem "After All Not to Create Only" (later titled "Song of the Exposition") at the American Institute Exhibition in New York City in 1871 for $\$ 100$; the published text of that poem states that Whitman recited it to "23,000 people and 5-600 hushed workmen," and the preamble suggests another instance of Whitman's magnificent ability to puff himself:

His manner was at first sight coldly quiet, but you soon felt a magnetism and felt stirred. His great figure was clothed in gray, with white vest, no necktie, and his beard was unshorn as ever. His voice is magnificent, and is to be mentioned with Nature's oceans and the music of forests and hills. His gestures are few, but significant. Sometimes he stands with his hands in his breast pockets; once or twice he walked a few steps to and fro.

Just as Whitman imagined his unrhymed and unmetered verse to be as "liquid, billowy waves," so his auditors in this instance sensed (or were imagined to have sensed) in his vocalism a poet without affectation or a stultifying formality ( $W W W C, 1: 414)$. In that performance, we are told that he was "perfectly self-possessed," that his tonal modulation and impassioned delivery ("A few allusions of his poem were in a playful tone, but the main impression of markedly serious, animated, and earnest") met with hearty approval. ${ }^{17}$

Later in life, Whitman did make a name for himself as an orator, in particular through his Lincoln lecture, which was delivered nineteen times in eleven years and concluded with a recital of his popular elegy "O Captain! My Captain!" The speaking bureau manager James Pond records in Eccentricities of Genius (1900) that Whitman "gave a few readings under my management during his life," with one bringing in $\$ 1,800$ in receipts; of another event, at Madison Square Theatre on the 
anniversary of Lincoln's birthday, Pond notes that "just as he [Whitman] was about to recite 'My Captain,' a little girl, the granddaughter of [the poet] Edmund Clarence Stedman, walked out upon the stage and presented him with a beautiful bouquet." ${ }^{18}$ Traubel described his reading of the poem at the conclusion of his final lecture as done "with greatest effect-power and pathos," no doubt restrained in gesture as was the lecture, which was billed in 1887 as itself a "prose poem."19 Through his performance of his elegy for the slain President, he was earnestly performing patriotism. In the 1880 s, when Whitman gave public lectures and readings, he was asked to recite the poem so often that he exclaimed (in 1888), "damn My Captain. . . . I'm almost sorry I ever wrote the poem," though, he admitted, it had "certain emotional immediate reasons for being" ( $W W W C, 2: 304,333$ ).

Published to immediate acclaim in the New York Saturday Press, "O Captain! My Captain!" was widely anthologized during Whitman's lifetime. The poet was distressed, though, to find the punctuation of "O Captain! My Captain!" deranged in the initial printing. On page proofs for a second publication, Whitman crossed out the exclamation point at the end of the first line, replacing it with a semicolon; other punctuation marks at line ends also are amended. The editors apparently had erred by picking up earlier versions (what Whitman calls "bad perversions") of punctuation and whole lines that had appeared in the poem prior to Whitman's 1871 revision of it. (Whitman revised the poem in 1866 and again in 1871. ${ }^{20}$ His revisions suggest the care with which Whitman composed paralinguistic features on the page, trying to enforce particular vocal effects in order to carry through the urgencies of the personality behind the scripted word. In "A Font of Type" Whitman refers to the printer's arsenal as "This latent mine-these unlaunch'd voices-passionate powers, / Wrath, argument, or praise, or comic leer, or prayer devout." When he states parenthetically "(Not nonpareil, brevier, bourgeois, long primer merely)," he means that these points of type (listed in ascending order of size: 6-, 8-, 9-, and 10-point) are to be regarded as more than inert characters, "pallid slivers" though they may be; they are expressive of character, and must be enlisted by the page-bound poet as part of a carefully orchestrated system of vocal notation $(P P, 614)$.

As late as 1879 , Whitman still was projecting into the future an image of himself on the stump: "I intend to go up and down the land (in moderation,) seeking whom I may devour, with lectures, and reading of my own poems" (PP, 1301). The parenthetical qualifier "in moderation" suggests Whitman's understanding of the nervous exhaustion that such vocal expenditure could cause. The American neurologist George M. Beard noted in 1881 that "American oratory is partly the product 
of American nervousness. For success in the loftier phases of oratory, fineness of organization, a touch of the nervous diathesis are essential"; he concluded that "this delicacy of organization, united with Saxon force, makes America a nation of orators." ${ }^{21}$ Beard explains, then, that if American oratory relies on a certain fineness of temper, it also relies on a racial robustness. Whitman's use of the verb "devour" suggests his vision of oratory as a consuming of the audience, as the incorporation of many into one: "Notwithstanding the diversity of minds in such a multitude, by the lightning of eloquence, they are melted into one mass, the whole assembly actuated in one and the same way, become as it were, but one man, and have but one voice" (NUPM, 6:2239). The political dream of the masses congealed into a single voice, a single nation, lies at the heart of his republican performance aesthetic.

Indeed, the conjunction of oral performance and nationhood hearkens back to the textual foundation of the American republic itself, as do fictions of oral performance, with utterance standing as a figure for the making of the United States, a political entity that is imagined as "spoken into being." 22 Jay Fliegelman notes the ambivalence at the heart of understandings of orality in the eighteenth century: "In one view orality was 'an inner voice of emotion' and an expression of subjectivity. In another it was 'public-oriented oratorical communication,' a mode of expression in which national values and a common sensibility were to be articulated and reinforced or (if romanticized as preliterate) recovered." ${ }^{23} \mathrm{He}$ also has shown that the Declaration of Independence is a document made to be "heard as performance" rather than "read silently," coming as it does with recital directions: "The locations of the marks on the rough draft of the Declaration as well as the locations of the 'quotation marks' on the proof copy of the Dunlap broadside represent not breath or punctuational pauses but precisely what Jefferson discusses: rhythmical pauses of emphatical stress that divide the piece into units comparable to musical bars or poetic lines" $(24,10)$. With the text operating as score, telling the reader how to position the voice at any given moment, he finds that, "rather than merely standing in opposition to print, orality can also be, and in the eighteenth century often was, a defining characteristic of print, a set of cues within a text that signal it is to be heard by the ear (as performance) as much as it is to be read by the eye" (218). Such recital cues are designed to "compensate for the anonymity (the absence of a physical speaker) of written prose, and for whatever ambiguity was occasioned by that anonymity" (54).

In early editions of Leaves Whitman, in an effort to get his word heard, employs dots to separate words and phrases in an effort to instruct the reader as to how to hear the work and how to perform it when reading it aloud. ${ }^{24}$ These dots are not unlike those throughout the 
Declaration of Independence that attempt to instruct the voice as to how to posture in a public reading of it. Of the Declaration of Independence and its vocal markers, Fliegelman finds that such inscriptions of the body on the page "serve as print culture's compensation for the loss of an expressive oral mode, a compensation for the inadequacy of print culture to rise to the challenge of demonstrating rather than merely representing the affective" (55). He further notes that the oral readings of the Declaration that Jefferson's markings overtly contemplated made it "an event rather than a document. They [i.e., the readings] gave it a voice, which . . . was experienced emotionally and responded to vocally. Read out loud, the document that denounced a false community would galvanize the bond of a true one" (25-26). The Irish stage actor Thomas Sheridan's prosodic criticism, Lectures on the Art of Reading (the second part, The Art of Reading Verse, first published in 1775), where he advocates the elocutionary use of a natural language of the heart, influenced Jefferson's notation of the Declaration of Independence as well as Whitman's idea of oratory and his scoring of the page on the page, a scoring that similarly imagines vocalization as performing political power.

Whitman believed that it was through the thrilling directness of "live" performance-as opposed to some second-hand notation or recording of it - that a democratic society best could be substantiated. In his notebook entry of April 24, 1857, Whitman idealistically foresees himself on the national stage, "on occasion, at Washington to be, launching from public room, at the opening of the session of Congressperhaps launching at the President, leading persons, Congressmen, or Judges of the Supreme Court," with the ambition "always to hold the ear of the people" (NUPM, 4:1554). Early in his career, when he envisioned himself on the lecture circuit, he imagined holding forth in the seats of political power across the country, harboring "the idea of strong live addresses directly to the people, adm. 10 c., North and South, East and West - at Washington, - at the different State Capitols-Jefferson (Mo.) - Richmond (Va.) - Albany - Washington \& c-promulging the grand ideas of American ensemble liberty, concentrativeness, individuality, spirituality \&c \&c" (NUPM, 6:2234; my emphasis). Whitman further observed that "although the Lectures may be printed and sold at the end of every performance, nothing can make up for that irresistible attraction and robust living treat of the vocalization of the lecture, by me,- - which must defy all competition with the printed and read repetition of the Lectures" (NUPM, 2:407). Drawing a distinction between the live oration and a reproductive representation of it, Whitman insists on the superiority of the former.

Whitman was an insatiable consumer of live performance, including public declamation, theater, and opera. Peggy Phelan's notion that 
performance's only continued existence is in the spectator's memory coincides with Whitman's, although Whitman is dismayed by the fact that a performance is undocumentable and Phelan, who valorizes the live event as standing outside of "the economy of reproduction" and therefore possessing an "oppositional edge," does not. ${ }^{25}$ In sympathy with a Bowery reviewer's feeling of "regret that a great art should in its nature be transitory," Whitman quotes, "Well, this great thing [the live performance] has been, and all that is now left of it is the feeble print upon my brain, the little thrill which memory will send along my nerves, mine and my neighbors, as we live longer the print and thrill must be feebler, and when we pass away the impress of the great artist will vanish from the world"' (PP, 1210). Although Philip Auslander contends that the concept of "liveness" is not applicable to performance until the 1930s, after sound recording and motion pictures reach maturity, believing that writing is "not . . . a form of recording in this context," Whitman invoked the concept to remarkably similar effect and, moreover, set out to prove that writing itself, like speaking, can be a performance. Indeed, Phelan finds that the challenge for writing "is to re-mark again the performative possibilities of writing itself," and she advocates "the act of writing toward disappearance, rather than the act of writing toward preservation." 26

Whitman's fond recollection of the 1830s Bowery Theatre points to his fascination not only with participatory live performance but with the theater of masculinity as well: "pack'd from ceiling to pit with its audience mainly of alert, well dress'd, full blooded young and middleaged men, the best average of American-born mechanics . . . the whole crowded auditorium, and what seeth'd in it, and flush'd from its faces and eyes, to me as much a part of the show as any-bursting forth in one of those long-kept-up tempests of hand-clapping peculiar to the Bowery - no dainty kid-glove business, but electric force and muscle from perhaps 2000 full-sinew'd men" (PP, 1213). ${ }^{27}$ These working-class men enact their manhood as they become "a part of the show," performing a cultural identity as the actors perform a character on stage.

After hearing and seeing Emerson perform live in 1847, Whitman wrote enthusiastically in the Brooklyn Eagle about that event as well, sharing with Emerson a gendered vision of the forceful spoken word, which, both men believed, stood as a sign of masculine sexual and cultural potency. As David Porter says of Emerson, "to his mind the thundering affectiveness of the poet was a manly virtue to be preferred to the character of Bryant's poems, Greenough's sculpture, and Dr. Channing's preaching. Of these he said: 'They are all feminine or receptive and not masculine or creative." ${ }^{28}$ Emerson found himself instead "intoxicated by the ravishing pulpit eloquence of Edward Everett," 
noting "how joyfully \& manly he spreads himself abroad." 29 Similarly, Whitman claimed of the Italian tenor Bettini: "None have thoroughly satisfied me, overwhelmed me, but this man. Never before did I realize what an indescribable volume of delight the recesses of the soul can bear from the sound of the honied perfection of the human voice. The manly voice it must be, too," for the woman's by comparison is "but as the pleasant moonlight." ${ }^{30} \mathrm{He}$ also praises the orator Henry Ward Beecher, noting that it is "refreshing that his bold masculine discourses were without that prettiness and correctness of style that, say what we will, is very often accompanied by emptiness and something very akin to effeminacy." 31 The physique required for vital oratorical performance is that of a man, too, a "great leading representative man, with perfect power," Whitman remarks, drawing on Emerson's figure of the "representative man" who is both of his age and transcends it (NUPM, $6: 2234)$. In the 1856 version of his poem "Song of the Broad-Axe," this social construction of the spoken word shows again in his salute to "the brawniest breed of orators and bards," robust men endowed with the gift of prophetic speech (LGVar., 1:181). Each of these instances speaks to how Whitman imagines the performance of poetry as bound up in the performance of masculinity - a masculinity that takes the athletic and affective as indicators of nationality and patriotism.

\section{Mediatization, Authentication, and the Virtual Voice}

The "electricity" and "magnetism" that Whitman ascribes to the human voice, as well as his own "magnetizing effect," take on a scientific literalness when we start to consider the impact of magnetic recording - that is, electric and electronic signalling - on the spoken word in the U.S. in the nineteenth century. ${ }^{32}$ The poet's fascination with the phonograph, with the power to record and replay the human voice that it represents, led him (perhaps) to speak into that device in either 1889 or 1890, although in the early part of 1889 he still could only imagine such a system, as is revealed in this reported dialogue between Whitman and his friend and recorder Horace Traubel. Whitman states:

"my thinking apparatus seems to be O.K.: it's the rest of me that gets tired. If I could talk into a machine - if I didn't have to use a pen - my troubles would be over." "No doubt we will speak into machines some day and out of them too." W. asked: "Do you mean the telephone? We have that already." I said: "No: I mean a machine with a voice." W. looked at me quizzically: "Well-who knows: having gone as far as we have with these wonders why shouldn't other wonders follow?" (WWWC, 4:81)

It is telling that the poem that we have been willed on wax cylinder is "America" (or part of it), as the nation somehow stands for the 
(recorded) voice, and vice versa. In the grainy recording, which may or may not be Whitman's voice, we hear only the first four lines of the poem, but in its published form it reaches to six:

Centre of equal daughters, equal sons,

All, all alike endear'd, grown, ungrown, young or old,

Strong, ample, fair, enduring, capable, rich,

Perennial with the Earth, with Freedom, Law and Love,

A grand, sane, towering, seated Mother,

Chair'd in the adamant of Time. $(P P, 616)^{33}$

In his phonographic hailing of the United States, a mediatized vocalism comes to symbolize the political culture of democracy itself, the reciter's voice metonymically "enduring," "Perennial," perpetual, like the country itself. (Indeed, such a display of nationalism is perfectly in tune with Edison's agent Gouraud's display of American flags and Civil War scenes at demonstrations of the phonograph in London in the late 1880s.) The image of the democratic mother, who loves all her children equally, stands opposed to a "corporate, centralized, maleidentified model of power," as Betsy Erkkila sees it, and is meant "to counteract the centralized administration of the state and the aggressively capitalist and male-powered ethos of the new market economy" (262). Of course, the invention of the phonograph ushers in a new phase in the commodification of sound recording, and thus the image of the democratic mother seated outside the "economy of repetition" would seem to be undercut by the mechanically repeatable performer's voice on record.$^{34}$ With the metaphorical mother left out of the recorded reading (mention of her is deferred until the penultimate line), we might say that the referent is the audible voice itself, preserved "in the adamant of Time," and thus very much enclosed within the cultural economy as reproducible artifact.

Whitman's desire to transcend physical boundaries, to connect with ordinary men and woman in a genuine way, and to connect them with each other in and through time (powerfully enacted in a poem like "Crossing Brooklyn Ferry"), helps to explain his attraction to the new technology of voice recording. As John Picker explains, "unlike the telegraph and the telephone, the phonograph was explicitly designed for archival purposes and also ultimately to function without a specially trained and designated operator. Of the three forms, that is, only the phonograph offered a form of preservation through direct, immediate interaction with its audience." What Picker refers to as its "interactive potential" would have impressed Whitman, as would its capacity both to capture and transcend the lineaments of the body: "even as the phonograph rendered a speaker's voice immortal and disembodied his 
or her speech, it seemed to preserve in the distinct tones, accents, and breath of that voice a fragile mortality, the very corporeality that words on a page or sentiments in a poem lacked" $(111-112,116)$. As Jacques Attali also has pointed out, the earliest forms of sound recording, such as Edison's cylinder, "were intended to serve as secondary adjuncts to live performance by preserving it. As recording technology brought the live into being, it also respected and reinforced the primacy of existing modes of performance." ${ }^{35}$ An extension of the live, the recorded voice pointed back to a body in spontaneous performance, not replacing, but augmenting, it.

The questionable provenance of the 36-second recording (as the poet Bob Perelman writes in "An Alphabet of Literary History" of the artifact, "Ginsberg noted the Brooklyn accent of / Love. But is it still really / Walt?") has not kept it from being used precisely to promote an ideal of authenticity in American popular culture. ${ }^{36}$ A 2009 Levi's ad campaign titled "Go Forth" features two television spots. In one, a recording of the actor Will Geer reading Whitman's poem "Pioneers! O Pioneers!" on a Folkways album released in 1957 provides the soundtrack; it focuses on an originary youth culture of America. The other spot trades on the putative Whitman recording in an effort to remind consumers of the company's roots. It is set to a series of black and white images of San Francisco and post-Katrina New Orleans showing Americans of all types in bold action against a backdrop of fireworks, with the message one of self-reliance, resilience, and hope. (The ad campaign kicked off on the Fourth of July.) The Vice President of brand marketing for Levi's has said that the campaign is about "reconnecting with our authentic voice-our vision for the company and for the pioneer spirit of America" (my emphasis). ${ }^{37}$ It also asks visitors to the web site to rewrite parts of the Declaration of Independence and submit photos, video, and stories of "today's America," thereby affirming Whitman's own sense of the need to revise to keep up with the times: "I am the new American pioneer, looking forward, never back. No longer content to wait for better times. . . . I will work for better times. 'Cause no one built this country in suits."'

Whitman's voice has been crucial behind the screen as well, a form of commodity in the cultural economy that has served the purpose of authentication. For Martin Scorsese's film Gangs of New York (2002), Daniel Day-Lewis modeled his Bowery boy speech after the alleged extant Whitman recording, in his pursuit of authenticity in his tonal recreation of nineteenth-century New York. Dialect coach Tim Monich notes that on the wax recording, "the poet pronounces 'world' as 'woild,' and the 'a' of 'an' nasal and flat, like 'ayan'"; as he goes on to explain, "the 1840 s and 1860 s are too early for recordings, so I 
went back to period sources, humorous writings, poems, ballads, and newspaper clippings to get an idea of what New Yorkers sounded like in those days. I also listened to early recordings of people who were born and raised in the period, for instance a recording of Walt Whitman." To prepare for the part of Bill "the Butcher" Cutting, Day-Lewis not only listened to the recording but immersed himself in the poetry of Whitman and would recite "Crossing Brooklyn Ferry" to get his own speech rhythms in place. ${ }^{38}$

In 1891, the poet himself weighed in on the place of Leaves in the cultural economy, somewhat surprisingly championing copyright protection. Whitman went so far as to sign a petition for the copyright law of 1891, an act that bespeaks his desire to exert control over his body of writing, to claim ownership of it; he also realized that such a law would spur the growth of American letters generally. Add to this Whitman's notion of a "definitive edition" of Leaves, a notion that would look to violate the very idea of text-as-process, and one begins to wonder just what happened to Whitman in his old age.

In the so-called death-bed edition of Leaves, the author carefully recites on the copyright page its full publication history in his assertion of authorial rights, adding that "as there are now several editions of L. of G., different texts and dates, I wish to say that I prefer and recommend this present one, complete, for future printing, if there should be any; a copy and fac-simile, indeed, of the text of these 426 pages." In the prefatory poem to this final edition, Whitman uses the present participle "owning" in a way that lights up the copyright information detailed on the next page: "Ever and ever yet the verses owning — as, first, I here and now, / Signing for Soul and Body, set to them my name," ( $P P, 148$, 147). After the comma in the 1876 "Author's Edition," the 1882 "Author's Edition," and the 1888 Complete Poems E Prose, Whitman signs his name in black ink; in the 1891-92 edition, we get his autograph in facsimile. The mention of "fac-simile" (an exact copy or reproduction) in the copyright notice and the appearance of a facsimile signature at the end of the poem throws into relief the question of representation versus reproduction. As Peggy Phelan observes, performance is nonreproductive (that is, it cannot be saved or repeated), and throughout his career, as we have seen, Whitman essentially engaged a performative writing, not only through his use of performative (as opposed to constative) utterances, but through his radical revisioning of his poetry; he was "writing toward disappearance," and not writing toward preservation, by keeping his texts in a state of change. At the end of his life, though, Whitman would seem to be less opposed to reproduction, as he seeks to congeal the text once and for all in light of his own mortality (disappearance). Indeed, the lines, "I was chilled with the cold types and 
cylinder and wet paper between us. / I pass so poorly with paper and types . . . . I must pass with the contact of bodies and souls," notably disappear from the untitled second poem of the 1855 Leaves (later titled "A Song for Occupations") in the death-bed edition.

However, there is an alternate way to view this statement of ownership and his recitation (I use the term pointedly) of the publishing history of Leaves that squares with his long adherence to ideals of performativity. As Martin Buinicki argues, "unlike those earlier copyright pages that highlight Whitman's identity as author of the text, here it is as though the citation of previous editions itself conveys Whitman's identity and does the work of authentication and possession once accomplished through his name alone. . . . Each edition, Whitman stresses, is a 'different text,' and his recommendation of this last edition, following as it does an exhaustive list of previous editions, highlights the unique identity of those preceding texts, each a separate embodiment of Walt Whitman." ${ }^{39}$ In effect, Whitman is re-citing (or re-siting) these editions in such a way as to confirm the authenticity of his own identity — an identity that is not stable, but in flux, responsive to changing cultural conditions. In "Walt Whitman's Last," he vouches that "every page of my poetic or attempt at poetic utterance . . . smacks of the living physical identity, date, environment, individuality, probably beyond anything known," and some of these contextual items certainly are brought out in his copyright recitation of past editions of Leaves (PP, 1369).

Even so, the matter of reproduction and its aim of preservation does not fade away, as Whitman looks to a literary archive to keep him in memory. In his 1872 poem "Souvenirs of Democracy" (in As a Strong Bird on Pinions Free), which becomes, in 1881, "My Legacy," Whitman again takes advantage of the process of stereotyping by assigning a facsimile of his signature beneath the poem. The following lines appear in 1872, closing out the first stanza of the poem, in a description of the act of the "business man" bequeathing his remains: "Parceling out with care-And then, to prevent all cavil, / His name to his testament formally signs" (LGVar., 3:633). In 1872 the poem ends with the poet arranging his affairs as well:

Only these Souvenirs of Democracy - In them - in all my songs - behind me leaving,

To You, whoever you are, (bathing, leavening this leaf especially with my breathpressing on it a moment with my own hands;

- Here! feel how the pulse beats in my wrists!- how my heart's-blood is swelling, contracting!)

I will You, in all, Myself, with promise to never desert you,

To which I sign my name,/

Walt Whitman [facsimile signature] (LGVar., 3:634) 
In 1881, though, these lines disappear, replaced by the following meditation: "Yet certain remembrances of the war for you, and after you, / And little souvenirs of camps and soldiers, with my love, / I bind together and bequeath in this bundle of songs" (LGVar., 3:634). Whitman's reproduction of his signature on the page, a personal token, or souvenir, of himself, is substituted for by the war, which is meant to stand in metonymic relation to himself and his entire poetic project. As Phelan argues, performative writing is metonymic (as opposed to metaphoric) in so far as it "works to secure a horizontal axis of contiguity and displacement," and Whitman's commitment to that figure of speech in the final version of the poem suggests his fundamental ambivalence in the face of absence (150).

This displacement may have had something to do with the poet's growing celebrity, too, with his discovery that often souvenirs of himself (as in the form of a signature) had the "heart's-blood" drained from them. Whitman increasingly worried about such tokens, bristling at the commodification of presence, as did other famous writers of his day. $\mathrm{He}$ spoke often to his friend Horace Traubel about the stream of autographseekers hounding him for signs of himself, and he was uncomfortable with the idea of someone collecting his autograph without having any connection to him or his work, with the idea of the reification of the self in the autograph generally. To Traubel, he reports:

"I knew a man in Washington - an expert there-who said once, when he leaned over my shoulder (I was working) - that my signature was one of the hardest he knew to imitate. I asked, is it so? And he assured me-yes, its very simplicity protects it. And he himself had a wonderful pen - could imitate pretty near any signature at will, for instance. Had a distinct genius of the sort. And I have often thought of it since." I told W. every bank teller would give him the same assurance. "That makes it more curious still. It must be as the expert said - its very simplicity-just as simplicity, truth, can never be imitated." (WWWC, 8:276)

The sense of the impossibility of anyone's imitating his autograph pleases Whitman so much because he feels that it proves both his authenticity and basic morality. That a reproduction (or counterfeit) of it cannot be made allows Whitman to believe in the idea that his own Leaves, superintended by himself, expressed truth simply, sent into the world in what he calls "honest type," a mechanical equivalent of his own cursivity. His alleged irreproducibility underwrites his uniqueness and maintains his esoteric nature, his "aura," a "quality" Whitman called "most real, but wholly indefinable" (WWWC, 5:119). When someone once questioned whether his signature was real (in a copy of Leaves that his publisher David McKay was trying to sell), Whitman expressed irritation, saying, "we are anxious to sell the books, God knows, but only to those who will 
accept the authenticity of the signature as it stands" ( $W W W C, 4: 396)$. Whitman's ideal reader is someone who takes on faith the authenticity of his work and of his presence within the work, someone who puts trust in character and whose ethical sense can be counted on.

Questions of authenticity and reproducibility also interestingly bear on the recording apparatus of Traubel himself and his "recital" of Whitman's conversations in his final years, a part of the continuing story of Whitman's performativity and of our performative reenactment of Whitman and his texts. In Traubel's address to the reader in the preface to the first installment (1906) of the multi-volume With Walt Whitman in Camden, he informs us:

My story is left as it was originally written. I have made no attempt to improve it. I have taken nothing off and put nothing on. . . . Here is the record as it virginally came from my hands in the quick of the struggle it describes. . . . The formal grace of the recital might have been improved. I have preferred to respect its integrity. To let it remain untouched by a censorship. To let it continue, for good or bad, in its then native atmosphere. I do not want to reshape those years. I want them left as they were. I keep them forever contemporary. I trust in the spontaneity of their first inspirations. (vii)

If Traubel leaves matters unchanged in his "recital" of Whitman's spoken word, Whitman worked otherwise; indeed, Whitman's modus operandi is precisely the reverse of Traubel's, as he finds that the only way to keep his poems "forever contemporary" is to revise them through time. Traubel's recorded conversations are described as a "virtual transcript" of his daily conversations with Walt ("It talks his words"), his recording a valuable archive even if it is only "virtual," that is, not the exact rendering of speech that a phonograph would provide ( $W W W C, 1$ :viii). However, as Traubel's contemporary Harrison Morris attests, like a phonograph, "Horace has caught the very accent of Walt's voice. . . . I can detect the phrase and modulation of Walt's slow hesitating and sonorous speech on every page of Traubel's . . . imperishable files." ${ }^{\prime 4}$

The notion of the "virtual" leads us to the ways in which these matters resound around and through Whitman in a digital age. With hypertext, we find ourselves in a condition of infinite reproducibilityone that poses a challenge to current copyright laws. As Kenneth M. Price has remarked, "the complicated textual history of Whitman's poetry makes it ideally suited to hypertext. By 'hypertext' we mean an electronic document characterized by links that allow readers to experience the text in various sequences as they choose to follow different avenues of information via connecting points." He particularly points to "the multiplicity of Whitman materials and his habit of process writing" as conditions that make him suitable for presentation online. ${ }^{41}$ The poem as event, with the work not identical to any one graphical or per- 
formative realization of it, obtains here. By being able to click through various versions of a single poem-or looking at the changing shape of Leaves as a sequence of poems over its six editions-we are involved as readers "in a less univocal process": "Hypertext encourages lively, even aggressive reading because it calls for active participation." In a wired state, we are no longer passive recipients of the word; rather, we can determine what we will read or hear, and when, operating in our own way improvisationally.

Not only is Whitman's performative quality captured best by hypertext; so is his publicity most fully realized, as Whitman is able to reach out to masses of readers, on an international basis, through electronic media. As Price observes: "The Walt Whitman Hypertext Archive has the great advantage of being able to distribute, in digital form, large amounts of material at low cost and thus to make rare Whitman itemsonce restricted to those able to undertake expensive travel-available to a broad audience." Indeed, Whitman sensed early on the benefit of electrotype and new reproduction technologies to his project of communicating to the American people en masse. His unpublished prose tract "The Eighteenth Presidency!" (1856), which he wrote toward the close of Buchanan's term in office and before the election of Lincoln and which is concerned with greed and the treatment of American workers, encouraged those reading it to "circulate and reprint this Voice of mine for the working-men's sake. I hereby permit and invite any rich person, anywhere, to stereotype it, or re-produce it in any form, to deluge the cities of The States with it, North, South, East, and West" (PP, 1347). Notwithstanding his subsequent embrace of copyright, he recognizes here that it is only through mass reproduction of the text, and the disregard of copyright, that it can be properly publicized, and it is ironic that the tract was not published in Whitman's lifetime. The material text of Leaves was read as a sign of his publicity as well, with a reviewer of the 1860 edition noting that it "is electrotyped for the sake of cheapness, the publishers evidently designing to sell it by millions, if possible." ${ }^{\prime 2}$

In "Note at End of Complete Poems and Prose," Whitman suggests that it has in fact not been his own "voice" that has generated Leaves, which instead stands as "an autochthonic record and expression, freely render'd, of and out of these 30 to 35 years [1855-1888] — of the soul and evolution of America" (PP, 1364). Again detracting from his own authorial agency, in the preface to his 1872 booklet As a Strong Bird on Pinions Free, he explains that "Leaves of Grass,' already publish'd, is, in its intentions, the song of a great composite democratic individual, male or female. And following on and amplifying the same purpose, I suppose I have in my mind to run through the chants of this volume, (if ever completed,) the thread-voice, more or less audible, of an ag- 
gregated, inseparable, unprecedented, vast, composite, electric democratic nationality" (PP, 1028-1029). Whitman has Emerson in mind and feels free to revise him, noting that "Emerson says manners form the representative apex and final charm and captivation of humanity: but he might as well have changed the typicality to voice" $(P P, 1293)$. Whitman knew well the representative power of the voice, its symbolic motive: for him, its exercise performed the republic itself, from "the still small voice vibrating" on "Election Day, November, 1884 " $(P P, 620)$ to the high-amp "barbaric yawp" sounding over the roof-tops.

\section{Rutgers University, Camden}

\section{NOTES}

1 This is the title, wording, and punctuation of the line from the 1881 edition of Leaves of Grass on. See Walt Whitman, Leaves of Grass: A Textual Variorum of the Printed Poems, ed. Sculley Bradley, Harold W. Blodgett, Arthur Golden, William White (New York: New York University Press, 1980), 197. Hereafter, LGVar.

2 Horace Traubel, With Walt Whitman in Camden (Various publishers, 1906-1996), 1:414. Hereafter, $W W W C$.

3 Walt Whitman, Complete Poetry and Collected Prose, ed. Justin Kaplan (New York: Library of America, 1996), 727. Hereafter, PP. In a notebook, Whitman states that "from practising loud pieces with the voice, I have fallen into a serious fault of too strong and frequent emphasis, from repeating the Shakesperian [sic] passages, Caesar \& Richard 3d." (Walt Whitman, Notebooks and Unpublished Prose Manuscripts, ed. Edward F. Grier [New York: New York University Press, 1984], 6:2237-2238. Hereafter, NUPM.)

4 Ernest Legouvé, The Art of Reading, trans. Edward Roth (Philadelphia: Claxton, Remsen, and Haffelfinger, 1879), 89.

5 Walt Whitman's Workshop: A Collection of Unpublished Manuscripts, ed. Clifton Joseph Furness (Cambridge, MA: Harvard University Press, 1928), 27. Hereafter, $W W W$.

6 On Gems from Walt Whitman, see Ed Folsom, “Leaves of Grass, Funior: Whitman's Compromise with Discriminating Tastes," American Literature 63 (December 1991), 641-663; on the Haldeman-Julius "Little Blue Books," see Kenneth M. Price, "Whitman in Selected Anthologies," Virginia Quarterly Review 81 (Spring 2005), 147-162.

7 [Walt Whitman], "Walt Whitman and His Poems," The United States Review 5 (September 1855), 205-212.

8 In my forthcoming book American Poetry in Performance: From Walt Whitman to Hip Hop (Ann Arbor: University of Michigan Press), I demonstrate the ways in which Whitman revises his poetry line by line in an effort to keep it in an unfixed state and thus in line with his poetics of liveness.

9 In Orality and Literacy: The Technologizing the Word (New York: Methuen, 1982), Walter J. Ong coins the term "secondary orality," which, as opposed to "primary orality," that is, the orality of preliterate cultures, is "essentially a more deliberate and self-conscious orality, based permanently on the use of writing and print" (3). 
10 These words appear in an advertisement for Leaves in Whitman's As a Strong Bird on Pinions Free (1872).

11 Quoted in Randall Knoper, Acting Naturally: Mark Twain in the Culture of Performance (Berkeley: University of California Press, 1995), 27-28.

12 Justin Kaplan, Walt Whitman: A Life (New York: Perennial, 2003), 263.

13 John Burroughs noted in October 1862 that "Walt Whitman is at Pfaff's every night" (quoted in Kaplan, 263).

14 Walt Whitman, The Correspondence, ed. Edwin Haviland Miller (New York: New York University Press, 1969), 1:163.

15 Richard Maurice Bucke, Walt Whitman (Philadelphia: D. McKay, 1883), 53. Contrarily, some Whitman biographers have stated that Whitman's voice was "highpitched," perhaps as a result of his stroke (see Larry D. Griffin, "Walt Whitman's Voice," Walt Whitman Quarterly Review 9 [Winter 1992], 125-133). The poet Jack Foley wonders whether that description is a result of homophobia (O Powerful Western Star: Poetry \& Art in California [Oakland, CA: Pantograph Press, 2000], 144). The contents of Whitman's "Reading Book," the book of edited poems that he used as a text in public readings, are enumerated in Walt Whitman's Workshop, 204-206.

16 In a notebook, Whitman writes that "a great style of reading or declaring has the secret, sane, non-theatrical quality of the style of nature's workmanship," and that "the eloquent man is natural" and "must be earnest and honest" (NUPM, 2238, 2240, 2241).

17 After All Not to Create Only (Boston: Roberts Brothers, 1871), n.p.

18 J. B. Pond, Eccentricities of Genius (New York: G. W. Dillingham, 1900), 497.

19 Quoted in David Haven Blake, Walt Whitman and the Culture of American Celebrity (New Haven: Yale University Press, 2006), 189, 192-193.

20 This letter is archived on the Library of Congress American Memory web site.

21 George M. Beard, American Nervousness: Its Causes and Consequences (1881; rpt. New York: Arno Press, 1972), 80-81.

22 See Christopher Looby, Voicing America: Language, Literary Form, and the Origins of the United States (Chicago: University of Chicago Press, 1996).

23 Jay Fliegelman, Declaring Independence: Fefferson, Natural Language, and the Culture of Eloquence (Stanford: Stanford University Press, 1993), 15.

24 C. Carroll Hollis, "Rhetoric, Elocution, and Voice in Leaves of Grass: A Study in Affiliation," Walt Whitman Quarterly Review 2 (Fall 1984), 1-21. Also see C. Carroll Hollis, "Tallying, Vocalizing All': Discourse Markers in Leaves of Grass," in Walt Whitman: The Centennial Essays, ed. Ed Folsom (Iowa City: University of Iowa Press, 1994), 61-67.

25 Peggy Phelan, Unmarked: The Politics of Performance (New York: Routledge, 1993), 146.

26 Philip Auslander, Liveness: Performance in a Mediatized Culture (New York: Routledge, 1999), 58; Phelan, 148. 
27 As Eric Lott affirms, "this was indeed a 'manly' preserve, a sphere of traditional male prowess and bravado whose turf loyalties were as likely to result in individual or gang violence as in the camaraderie of the saloon" (Love and Theft: Blackface Minstrelsy and the American Working Class [New York: Oxford University Press, 1995], 86).

28 David Porter, Emerson and Literary Change (Cambridge, MA: Harvard University Press, 1978), 107.

29 Quoted in B. L. Packer, Emerson's Fall: A New Interpretation of the Major Essays (New York: Continuum, 1982), 1.

30 Quoted in F. O. Matthiessen, American Renaissance (New York: Oxford University Press, 1968), 559.

31 Quoted in David S. Reynolds, Walt Whitman's America: A Cultural Biography (New York: Vintage, 1995), 173.

32 Larry D. Griffin, "Walt Whitman's Voice," Walt Whitman Quarterly Review 9 (Winter 1992), 125-133. See also Ed Folsom, "The Whitman Recording," Walt Whitman Quarterly Review 9 (Spring 1992), 214-216; and William Grimes, "On Tape, Scholars Think They Hear Walt Whitman Reading," New York Times (March 16, 1992), Sec. B:1-2.

33 To listen to the 36-second wax cylinder recording, visit http://whitmanarchive. org/multimedia/index.html.

34 John M. Picker, Victorian Soundscapes (New York: Oxford University Press, 2003), 117.

35 Quoted in Philip Auslander, "Live from Cyberspace," PAf: A fournal of Performance and Art 24.1 (2002), 16.

36 Bob Perelman, The Marginalization of Poetry: Language Writing and Literary History (Princeton, NJ: Princeton University Press, 1996), 149. In conversation with Jack Foley, Ginsberg surmises that it is Whitman on the recording based on the Brooklyn accent given to the word ample (Foley, O Powerful Western Star, 144).

37 See Laura Swinton, "Levi's rebrand for Independence Day," Draper's (July 2, 2009), available: www.drapersonline.com.

38 See Fergus M. Bordewich, "Manhattan Mayhem," Smithsonian (December 2002), 44-52.

39 Martin T. Buinicki, "Walt Whitman and the Question of Copyright," American Literary History 15.2 (2003), 269, 270.

40 Harrison S. Morris, Walt Whitman: A Brief Biography with Reminiscences (Cambridge, MA: Harvard University Press, 1929), 96.

41 Georgetown University's Crossroads Project interviewed Ken Price in 1996; a full transcription is available on the Walt Whitman Archive (www.whitmanarchive.org/ about/articles/anc.00005.html).

42 "Walt Whitman And His Critics," The Leader and Saturday Analyst (June 30, 1860), 614-615. 